\title{
Taphrognathus carinatus (Higgins \& Varker) (Conodonta, Vertebrata) from the Lower Carboniferous of Belgium, and international correlation using taphrognathids
}

\author{
MARK A. PURNELL ${ }^{1}$, PETER H. VON BITTER ${ }^{2}$ \& ERIC GROESSENS ${ }^{3}$ \\ ${ }^{1}$ Department of Geology, University of Leicester, University Road, Leicester LE1 7RH, UK \\ (e-mail: map2@le.ac.uk) \\ ${ }^{2}$ Department of Palaeobiology, Royal Ontario Museum and Department of Geology, University of Toronto, 100 Queens Park, Toronto, \\ Ontario, Canada, M5S 2C6 \\ ${ }^{3}$ Service Géologique de Belgique, Rue Jenner, 13, B-1000 Bruxelles, Belgium
}

\begin{abstract}
Lower Carboniferous conodont faunas from shallow shelf and more offshore settings have few taxa in common and correlation is difficult. Consequently, reports of shallow shelf taphrognathid conodonts and indications that the Taphrognathus transatlanticus Range Zone may be recognizable in Lower Carboniferous sequences in Belgium (Conil et al., 1991) are potentially significant for international correlation using conodonts. Here we present a review of the usefulness of taphrognathid conodonts in international correlation and a brief summary of the current state of their taxonomy. Taphrognathus transatlanticus von Bitter \& Austin, 1984 cannot be accommodated within Taphrognathus Branson \& Mehl, 1941 and, until a new genus is erected, it is best referred to as aff. Taphrognathus transatlanticus. The status of $T$. rhodesi as a distinct species is uncertain. The affinities of $T$. alaskensis are currently obscure, but we strongly doubt that it is a species of Taphrognathus. Regarding Belgian taphrognathids, examination of specimens from the collection reported by Conil et al. (1991) reveals that Taphrognathus carinatus (Higgins \& Varker, 1982) is present. This extends the geographical range of T. carinatus beyond the UK, but we are unable to confirm the presence of aff T. transatlanticus in Belgium. J. Micropalaeontol. 21(2): 97-104, December 2002.
\end{abstract}

\section{INTRODUCTION}

Few of the conodont animals that swam in the shallows of Carboniferous seas ventured far from shore. During the Dinantian near shore environments were generally inhabited by cavusgnathid conodonts such as Taphrognathus, Clydagnathus and Cavusgnathus. Taxa more characteristic of more open marine shelf and basinal settings, such as Gnathodus and Lochriea, rarely moved into the most shoreward environments. This ecological partitioning has had a marked affect on the development of conodont biozonation of the Dinantian and separate zonal schemes have developed, commonly referred to as 'shelf' and 'basin' biozonations. Because there are few taxa common to both environmental settings, correlation between the two can be problematic. Furthermore, because of their preference for shallow water, taxa found in shelf faunas have rather patchy geographical distributions, which generally results in shelf biozonations being useful only over relatively small areas.

These difficulties are further compounded by the generally poor recovery of conodonts from parts of the Dinantian. Faunas are limited in both abundance and diversity and barren intervals are common. Most of the Arundian in the Avon Gorge of the UK, for example, yields no conodonts (Rhodes et al., 1969; Varker \& Sevastopulo, 1985) and in Sweet's (1988) compilation of conodont ranges by zone the Viséan is characterized as an interval with no widely recognized zones. The problems of poor faunas are particularly apparent in shallow marine sequences such as those of Atlantic Canada (von Bitter, 1976; von Bitter \& Plint-Geberl, 1982; von Bitter \& Austin, 1984; Plint \& von Bitter,
1986; von Bitter et al., 1986, von Bitter \& Plint, 1987; Purnell \& von Bitter, 1992), the Northumberland trough (Armstrong \& Purnell, 1987, Purnell, 1989, 1992) in northern England and the Scottish borders, and the Ravenstonedale area of Cumbria (Higgins \& Varker, 1982). It has proven very difficult to correlate these shelf sequences with those deposited in more open marine and deeper-water basinal settings, such as the type area for the Dinantian in Belgium. Correlation of the Ravenstonedale sequence is of particular significance because the area was designated by Garwood (1913) as the type area for the Lower Carboniferous of northern England; it remains important for British Carboniferous stratigraphy and correlation (Higgins \& Varker, 1982; Cossey \& Adams 2002).

We report here the first occurrence of Taphrognathus carinatus (Higgins \& Varker) outside northern England and review the usefulness of taphrognathid conodonts for international conodont-based correlation of Lower Carboniferous strata.

\section{SYSTEMATIC PALAEONTOLOGY OF TAPHROGNATHUS}

Element notation and terms for orientation follow Purnell et al. (2000). Throughout this paper, we use inverted commas to indicate that a taxon name is obsolete (Jeppsson \& Merrill, 1982). The taxonomy of Taphrognathus species is not the focus of this paper and, except for T. carinatus, we do not present synonymy lists for species. We do, however, provide references to recent complete synonymies. The $T$. carinatus synonymy is annotated using the symbols recommended by Matthews (1973) 
Genus Taphrognathus Branson \& Mehl, 1941

1941 Taphrognathus Branson \& Mehl: 181.

non 1947 Taphrognathus Welles.

1975 Cloghergnathus Austin in Austin \& Mitchell: 48.

Type species. Taphrognathus varians Branson \& Mehl, 1941, by original designation.

Diagnosis. Modified from Purnell (1992). $\mathrm{P}_{1}$ element carminiscaphate to anguliscaphate with conspicuous oral trough; position of 'anterior' (= dorsal) free blade variable, but all species include forms with a medial blade and forms with a left or right lateral blade; 'posterior' (= ventral) end of free blade subequal in height to 'anterior' end of parapets in sinistral and dextral elements; parapets nodose or transversely ridged; aboral cavity bilaterally symmetrical to moderately asymmetrical; $\mathrm{P}_{2}$ element angulate; $M$ element makellate; $S_{0}$ element alate; $S_{1}$ element bipennate with conspicuous inward curvature of 'anterior' (= rostral) process; $\mathrm{S}_{2}$ element bipennate, gently arched; $\mathrm{S}_{3}$ and $\mathrm{S}_{4}$ elements bipennate with straight 'posterior' (= caudal) process and gently incurved 'anterior' (= rostral) process.

Remarks. Since its erection as a monotypic genus five additional species have been assigned to Taphrognathus: T. rhodesi (Austin in Austin \& Mitchell, 1975), T. cravenus (Metcalfe, 1981), T. alaskensis Savage \& Barkeley (1985), T. carinatus (Higgins \& Varker, 1982) and T. transatlanticus von Bitter \& Austin, 1984 (herein assigned to aff. T. transatlanticus). We discuss T. varians, $T$. carinatus and aff. T. transatlanticus in subsequent sections. $T$. rhodesi differs from $T$. varians only in the spacing of the ridges ornamenting the platform of the $\mathrm{P}_{1}$ element (Austin in Austin \& Mitchell, 1975; Purnell, 1992). Only two specimens are known (Austin \& Mitchell, 1975) and we doubt that the true range of variation in $T$. rhodesi is narrow enough to distinguish it from $T$. varians, but this can only be resolved through study of more material. T. cravenus differs from $T$. varians in that the 'posterior' (= ventral) half of the platform is depressed relative to the 'anterior' (= dorsal) half. Metcalfe (1981) also illustrated three $\mathrm{P}_{1}$ elements with a depressed posterior platform that he did not include in $T$. cravenus; he assigned these elements to $T$. rhodesi and $T$. globenskii. It seems that they were excluded from $T$. cravenus only in that they possessed a left lateral 'anterior' blade, Metcalfe (1981) considering the possession of a right lateral or medial blade diagnostic of $T$. cravenus. However, blade position is highly variable in other members of the genus, both within populations and through time, and it is probably not a reliable character for differentiating species of Taphrognathus (Purnell, 1992). We thus include the three $\mathrm{P}_{1}$ elements assigned by Metcalfe (1981) to T. rhodesi and T. globenskii within the range of variation of $T$. cravenus. Taphrognathus alaskensis is much younger than all other species of Taphrognathus. Without knowing the morphology of its $\mathrm{P}_{2}, \mathrm{~S}$ and $\mathrm{M}$ elements the affinities of $T$. alaskensis remain uncertain, but we strongly doubt that it is a species of Taphrognathus. T. cravenus and $T$. alaskensis are known only from the Craven Basin of northern England and southeastern Alaska, respectively. Consequently, their use in international correlation is, at present, limited; we do not consider them further here.
Taphrognathus varians Branson \& Mehl, 1941

(Pl. 1, figs 1-4)

Diagnosis. Modified from Purnell (1992). $\mathrm{P}_{1}$ elements bear an 'anterior' (= ventral) blade that is free for most of its length; blade denticles subequal or increasing in size anteriorly, may be largest around mid-point of blade; height of 'posterior' (= dorsal) end of free blade and 'anterior' (= ventral) end of parapets subequal; parapets transversely ridged; $\mathrm{P}_{1}$ elements straight or gently arched in 'lateral' view.

Remarks. Purnell (1992) included a full synonymy and description of $T$. varians and a detailed discussion of variation within the species.

Taphrognathus carinatus (Higgins \& Varker, 1982) (P1. 1, figs 5-9)

V*p 1982 Cloghergnathus carinatus Higgins \& Varker: 160, 161, pl. 18, figs $1-3,7-9,11$ only [ $\mathrm{P}_{1}$ elements].

v.p 1982 Cloghernathus non-platform elements; Higgins \& Varker: 161, pl. 18, fig 18 [ $\mathrm{P}_{2}$ element], fig. 19 [S $\mathrm{S}_{3 / 4}$ element], pl. 19 , figs $5,6,8$ [S $\mathrm{S}_{0}$ elements], fig. 20 [? $\mathrm{S}_{3 / 4}$ element] only [all referred to as Cloghergnathus carinatus in plate captions].

v? 1982 Lonchodina sp.; Higgins \& Varker: 164, pl. 18, fig. 17 [? $\mathrm{S}_{1}$ element], pl. 19, figs $1-3$ [? $\mathrm{S}_{2}$ elements].

v? 1982 Neoprioniodus sp.; Higgins \& Varker: 164, pl. 19, fig. 17 [M element].

v. 1985 Cloghergnathus carinatus Higgins \& Varker; Varker \& Sevastopulo: 200, pl. 5.5, figs. 6, 8, 10 [ $\mathrm{P}_{1}$ elements][cop. Higgins \& Varker, 1982, pl. 18, figs 1, 2, 7].

v. 1992 Taphrognathus carinatus (Higgins \& Varker); Purnell: 19, pl. 3, figs 10, 13 [ $\mathrm{S}_{0}$ elements], 14 [ $\mathrm{P}_{2}$ element], 15 [M element], pl. 4 , fig. $1\left[\mathrm{P}_{1}\right.$ element].

v? 1992 Taphrognathus carinatus (Higgins \& Varker); Purnell: 19, pl. 3, figs 11 [ $S_{1}$ element], 12 [ $S_{2}$ element $]$.

Diagnosis. Modified from Purnell (1992). $\mathrm{P}_{1}$ elements arched with short 'inner lateral' or medial 'anterior' (= ventral) blade one quarter to one fifth of element length; blade convex and crestlike, extending above height of parapets but equal in height at its 'posterior' (= dorsal) end to the inner parapet; parapets nodose or transversely ridged; medial carina developed in 'posterior' quarter of oral trough.

Remarks. This diagnosis is modified only slightly from Higgins \& Varker (1982). With the documentation of the intraspecific variation in $\mathrm{P}_{1}$ elements of $T$. varians, 'inner lateral' blade development and possession of a 'posterior' (= ventral) carina can no longer be considered diagnostic of $T$. carinatus alone (Purnell, 1992; contra Higgins \& Varker, 1982). However, the crestlike blade profile, larger blade denticles, the development of more nodose or bloated parapets, and the arching of the $\mathrm{Pa}$ element distinguish $T$. carinatus from all other members of the genus. All elements of this species tend to be robust, but it is possible that this is an ecophenotypic character as $T$. varians elements occurring with $T$. carinatus exhibit the same tendency. $\mathrm{P}_{1}$ elements are sinistral or dextral but always with an 'inner' or, less commonly, a more medial blade. 


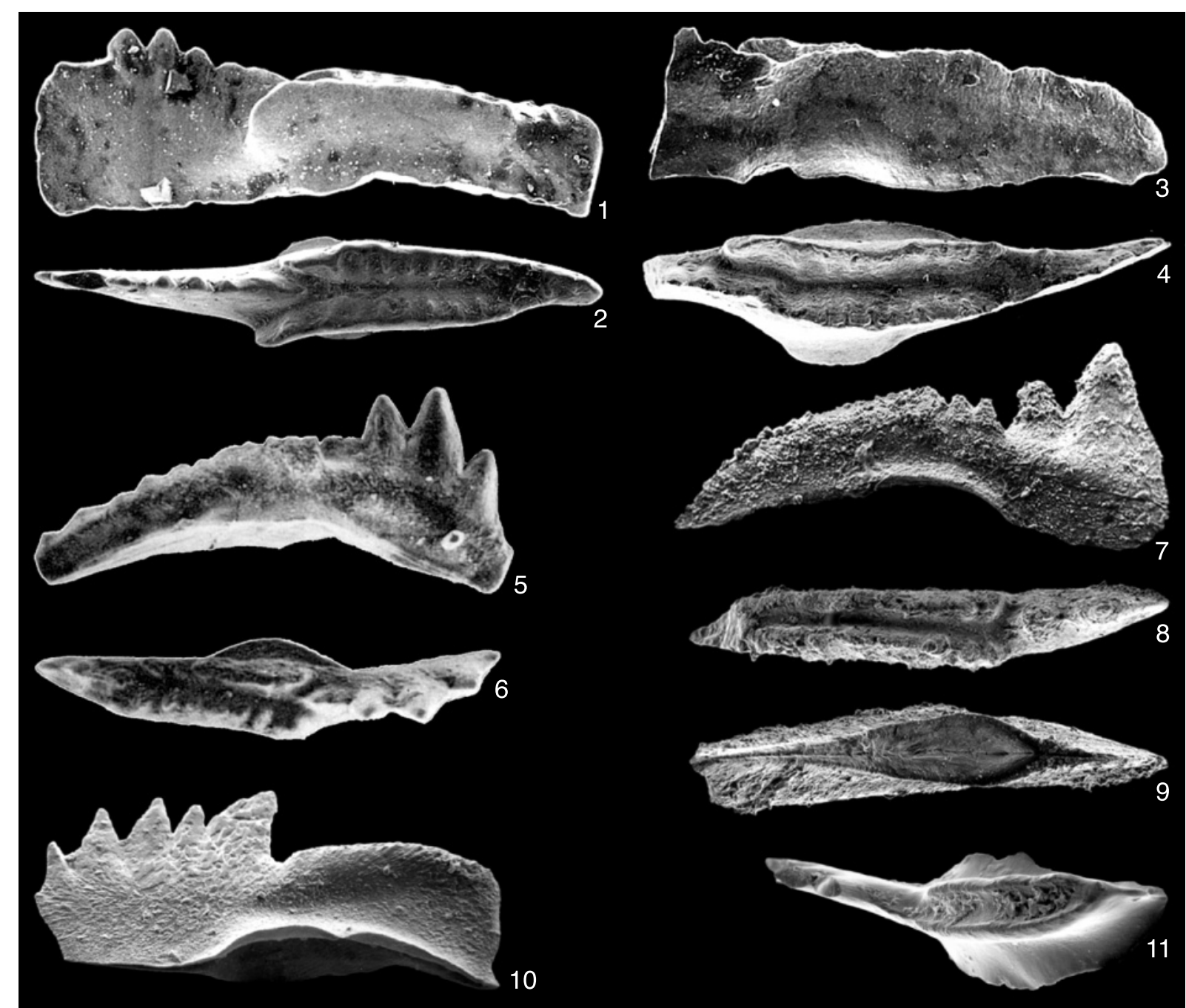

Explanation of Plate 1. figs 1-11. $\mathrm{P}_{1}$ elements of Taphrognathus varians, T. carinatus, and aff. T. transatlanticus: 1, 2, Taphrognathus varians, 'inner lateral' (caudal) and oral views of holotype, University of Missouri specimen C578-5 fig. 28 (Branson \& Mehl, 1941, pl. 6, fig. 28), × 60; 3, 4, Taphrognathus varians, 'outer lateral' (rostral) and oral views of $\mathrm{P}_{1}$ element with 'laterally' positioned 'anterior' (ventral) blade from the type collection, University of Missouri specimen C578-5 fig. 34 (Branson \& Mehl, 1941, pl. 6, fig. 34), × 60; 5, 6, Taphrognathus carinatus, 'outer lateral' (rostral) and oral views of $\mathrm{P}_{1}$ element from type collection, Natural History Museum specimen PM X 1014 (Higgins \& Varker, 1982, pl. 18, figs 9 , 11), $\times 60 ; 7-9$, Taphrognathus carinatus, 'outer lateral' (rostral), oral, and aboral views of $\mathrm{P}_{1}$ element from Mazy, Belgium, specimen ROM 53996, $\times 100$; 10, aff. T. transatlanticus, 'lateral' view of $\mathrm{P}_{1}$ element, Royal Ontario Museum specimen ROM 38471 (von Bitter \& Austin 1984, pl. 17, fig. 4), $\times 150 ; 11$, aff. T. transatlanticus, oblique oral view of $\mathrm{P}_{1}$ element, holotype, Royal Ontario Museum specimen ROM 38474 (von Bitter \& Austin 1984, pl. 17, fig. 1), × 150. All specimens orientated with 'anterior'-'posterior' axis (dorso-ventral axis) horizontal.

In addition to re-illustrating one of Higgins \& Varker's (1982) figured $\mathrm{P}_{1}$ elements of $T$. carinatus (Pl. 1, figs 5, 6) we illustrate a specimen that represents the first record of $T$. carinatus outside northern England (Pl. 1, figs 7-9). This specimen is from a disused quarry at Mazy in the Orneau valley near the village of Onoz (localities 64 and 72 of Hance et al. (1981)), about $16 \mathrm{~km}$ west of Namur. It is a $\mathrm{P}_{1}$ element, almost complete, with only the 'posterior' (= dorsal) part of the platform missing. In all significant features it is indistinguishable from specimens of T. carinatus illustrated by Higgins \& Varker (1982).

aff. Taphrognathus transatlanticus (von Bitter \& Austin, 1984) (Pl. 1, figs 10-11)
Modified diagnosis. $\mathrm{P}_{1}$ elements with a free 'anterior' (= ventral) blade that is separated by a notch from the 'outer lateral' parapet; blade bears up to seven laterally compressed denticles, the largest of which, at 'posterior' end, is significantly higher than the 'anterior' (= dorsal) end of the parapets; parapets unornamented, the 'posterior' end of platform pointed and, in 'lateral' view, descends vertically.

Remarks. As noted by von Bitter \& Austin (1984), aff. Taphrognathus transatlanticus did not sit comfortably in Taphrognathus as then conceived, and this is still true. It differs from other species of the genus in a number of ways, such as the form of the ventral (='anterior') blade and the ornament of the parapets 


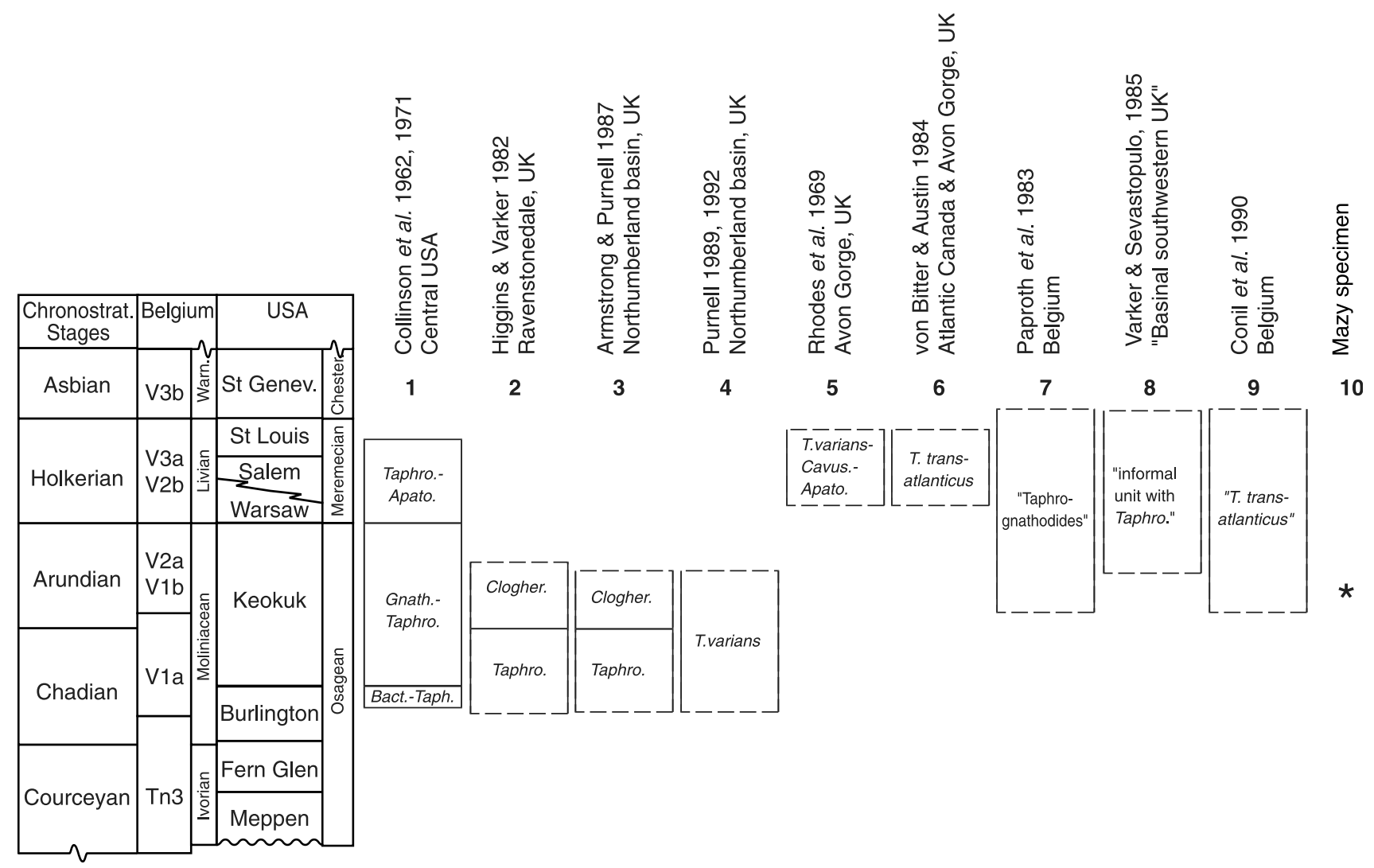

Fig. 1. Correlation of taphrognathid-based biozonations in the Lower Carboniferous of Europe and North America. Chronostratigraphic stages are those used by Harland et al. (1990). Correlation of the Belgian and USA sequences with chronostratigraphy is based on Brenckle \& Manger (1991). 1. Collinson et al. $(1962,1971)$ erected the Bactrognathus-Taphrognathus Assemblage Zone, The Gnathodus texanus s.s.- Taphrognathus Assemblage Zone and the Taphrognathus varians-Apatognathus? Assemblage Zone; none of these was based on the range of T. varians, but all included it as a characteristic species. 2. Higgins \& Varker (1982; 153-154) erected the Taphrognathus Partial Range Zone (probably a local range zone) based on the local range of $T$. varians. They considered the 'Cloghergnathus' Assemblage Zone as 'merely an interregnum between the disappearance of Taphrognathus and the appearance of Cavusgnathus', but the zone contains elements that we would assign to T. varians (e.g. pl. 18, figs 6, 10; see text). 3. The Taphrognathus Partial Range Zone and the 'Cloghergnathus' zone of Armstrong \& Purnell (1987) were derived from the zones erected by Higgins \& Varker (1982), and were based on local ranges. 4. Purnell's $(1989,1992) T$. varians Local Range Biozone was defined by the range of T. varians in the Bewcastle area of the Northumberland Trough. 5. Rhodes et al. (1969) defined the limits of the Taphrognathus variansCavusgnathus-Apatognathus Assemblage Zone as coinciding with the stratigraphic range of $T$. varians in the Avon Gorge (therefore a local range biozone). Austin (1974) recognized that $T$. varians was absent from this sequence and noted juvenile specimens of Cavusgnathus spp. 6. von Bitter \& Austin (1984) erected the aff. Taphrognathus transatlanticus Range Zone based on the range of aff. T. transatlanticus in Atlantic Canada and the Avon Gorge, UK., after they identified Taphrognathus-Cavusgnathus transitions of Rhodes et al. (1969) and the juvenile Cavusgnathus spp. noted by Austin (1974) from the Avon Gorge as aff. Taphrognathus transatlanticus. 7. The 'Taphrognathodides' [sic] zone of Paproth et al. (1983; table 2 and chart) was described as an informal unit characterized by the presence of taphrognathids. Groessens (1974) and Conil et al. (1976) showed ?Taphrognathus and Taphrognathus in the Belgian V2 and V2a respectively. 8. The 'informal unit with Taphrognathus' and the 'informal unit with taphrognathids' of Varker \& Sevastopulo (1985; table 6 and fig. 5.5) were extrapolated from the Belgian zonations; their table 6 shows no taphrognathid species within this unit. 9. The Taphrognathus transatlanticus interval of Conil et al. (1991) is a sequence of upper Moliniacean to middle Warnantian strata in Belgium yielding a few specimens of taphrognathids.

on $\mathrm{P}_{1}$ elements, and the morphology of the $\mathrm{P}_{2}$ and $\mathrm{S}$ elements. The intrarelationships of cavusgnathid conodonts are currently unclear, and it is possible that aff. T. transatlanticus represents a species of Patrognathus Rhodes, Austin \& Druce, 1969, Clydagnathus Rhodes, Austin \& Druce, 1969, or a new genus. Until these questions are resolved, however, there seems little purpose in erecting a new monotypic genus to accommodate aff. $T$. transatlanticus. Communication is best served by using open nomenclature, following the recommendations of Bengtson (1988), and discussing this species as aff. T. transatlanticus (von Bitter \& Austin, 1984).

\section{STRATIGRAPHIC RANGES OF TAPHROGNATHUS VARIANS AND T. CARINATUS, AND CHADIAN- HOLKERIAN TAPHROGNATHID-BASED ZONES}

In central USA, $T$. varians ranges through a broad interval that has been subdivided into three zones (Fig. 1). In the lowest of these, the 'Bactrognathus-Taphrognathus assemblage zone' (Collinson et al., 1962, 1971), T. varians is restricted to the upper third of the zone (Collinson et al., 1971). Baxter (1984, p. 247) suggested that Taphrognathus was absent from the Burlington Formation, but has since found it in the upper part of the formation in Missouri (pers. comm. to PvB, 1987). Collinson 
et al. (1971) indicated that T. varians occurs throughout their 'Gnathodus texanus s.s.-Taphrognathus assemblage zone', and defined the base of the succeeding 'Taphrognathus varians-Apatognathus? assemblage zone' (NB Apatognathus?= Synclydognathus Rexroad \& Varker (1992)) on the 'lowest common occurrence of Taphrognathus' (Collinson et al., 1971, p. 382). For details of the correlation of these zones into other areas of North America, see Thompson (1967), Thompson \& Fellows (1970), Ruppel (1979), Baxter \& von Bitter (1984), and Chaplin (1984).

Higgins \& Varker (1982) erected their Taphrognathus Partial Range Zone based on the local range of $T$. varians in Ravenstonedale in Cumbria, UK. The succeeding 'Cloghergnathus' Assemblage Zone contains Taphrognathus carinatus (their Cloghergnathus carinatus) but was described by Higgins \& Varker (1982, p. 154) as 'merely an interregnum between the disappearance of Taphrognathus and the appearance of Cavusgnathus'. As noted above, it is now known that $\mathrm{P}_{1}$ elements of $T$. varians may have a lateral 'anterior' (= ventral) blade and a 'posterior' $\left(=\right.$ dorsal) carina. Some of the $\mathrm{P}_{1}$ elements that Higgins \& Varker (1982, pl. 18, figs 4-6, 10) illustrated and identified as 'Cloghergnathus' carinatus from within their 'Cloghergnathus' zone in Ravenstonedale are, in fact, $T$. varians. We have been unable to examine Higgins \& Varker's unfigured material, but is seems likely that the Taphrognathus zone cannot be differentiated from the 'Cloghergnathus' zone using the stratigraphic ranges of $T$. varians and T. carinatus. The same applies in the Northumberland trough further to the north, and although Armstrong \& Purnell (1987) indicated that the Taphrognathus zone and the 'Cloghergnathus' zone could be recognized in the area, Purnell $(1989,1992)$ defined a single $T$. varians Local Range Biozone through the equivalent stratigraphic interval.

The only other authors to discuss taphrognathid-based zonation in the UK are Austin \& Davies (1984). Their figure 21 (p. 214) shows a sequence of shelf faunas including a Chadian 'Cloghergnathus' interval and a younger late Chadian to Arundian Taphrognathus interval. They stated, however, that knowledge of Chadian-Asbian shelf faunas was 'especially limited' and that the sequence of shelf faunas should not be used for correlation. Furthermore, they appear to have erroneously reversed what was at the time thought to be the relative stratigraphic order of 'Cloghergnathus' and Taphrognathus.

\section{STRATIGRAPHIC RANGE OF AFF. TAPHROGNATHUS TRANSATLANTICUS AND ARUNDIAN-ASBIAN TAPHROGNATHID-BASED ZONES}

Rhodes et al. (1969) erected a 'Taphrognathus variansCavusgnathus-Apatognathus assemblage zone' based, they claimed, on the range of $T$. varians through strata now recognized as Holkerian in age in the Avon Gorge, UK (Fig. 1). As noted by Austin (1974), however, T. varians is absent from this sequence. The elements figured as $T$. varians by Rhodes et al. (1969, pl. 13, figs 4, 5) are in fact Cavusgnathus hudsoni from the Scottish borders (Purnell, 1992).

Rhodes et al. (1969, pl. 13, figs 1-3) also illustrated 'Taphrognathus-Cavusgnathus transitions' from the Holkerian sequence in the Avon Gorge, and Austin (1974) noted the presence of what he took to be juvenile specimens of Cavusgnathus spp. in this interval. These specimens were subsequently identified as $\mathrm{Pa}\left(=\mathrm{P}_{1}\right)$ elements of aff. Taphrognathus transatlanticus by von Bitter \& Austin (1984), who erected the Taphrognathus transatlanticus range zone based on the range of the species in the Avon Gorge and in Atlantic Canada. Purnell (1992) reported Taphrognathus? transatlanticus? from northern Cumbria, UK, but the single equivocally assigned specimen is almost certainly a juvenile $T$. varians. The only other place from which aff. T. transatlanticus has been reported is Belgium. Here Groessens (1974) and Conil et al. (1976) indicated the presence of ?Taphrognathus and Taphrognathus in strata of ArundianHolkerian age, and Paproth et al. (1983, table 2 and chart) described the 'Taphrognathodides [sic] zone', an informal unit of this age characterized by the presence of taphrognathids. This unit was extrapolated from Belgium to the basinal sequences of the southwestern UK by Varker \& Sevastopulo (1985), even though their range charts (fig. 5.5) did not indicate taphrognathids ranging through this interval. Conil et al. (1991: 18) subsequently reported the occurrence of 'a few small taphrognathid-like conodonts' from Arundian-Asbian strata in Belgium and suggested that the interval from which they came 'might correspond' to the aff. Taphrognathus transatlanticus Zone. Although they stated that the zone had not been formally recognized in Belgium, they included the $T$. transatlanticus Zone in their conodont zonation (figs 2, 3, 4, 6) and plotted the stratigraphic range of aff. $T$. transatlanticus in the Belgian sequence (fig. 2).

\section{STRATIGRAPHIC RANGES OF TAPHROGNATHID SPECIES AND THEIR USE IN INTERNATIONAL CORRELATION}

Taphrognathus varians is a widespread species, known from various localities in North America and Europe. In the USA, $T$. varians ranges from the upper part of the Burlington Formation into the middle part of the St Louis Formation. Thus, following the correlations of the sequence in the USA with the chronostratigraphic stages in Brenckle \& Manger (1991), T. varians ranges from the lower Chadian into the upper Holkerian. In the upper part of this range, T. varians co-occurs with Cavusgnathus unicornis, which first appears in the middle St Louis Formation, but the 'Taphrognathus-Cavusgnathus transitions' noted by Rexroad \& Collinson (1963) are elements of T. varians (Purnell, 1992).

In the UK, T. varians ranges from the lower Chadian to the middle Arundian (cf. Riley, 1993). However, because we have not had access to the collection of Higgins \& Varker (1982) to determine how high T. varians (sensu Purnell, 1992) ranges, we cannot be certain of its last appearance in Ravenstonedale. If, as seems reasonable, we assume that $T$. varians ranged up to the top of the 'Cloghergnathus' zone, then its last appearance occurs at the base of an interval without conodonts. Similarly, in the Northumberland Trough the last $T$. varians occur at the base of a $c .100 \mathrm{~m}$ thick interval that yielded only a few stratigraphically un-diagnostic conodont elements. Thus, the true range of $T$. varians probably extends a little higher than shown in Figure 2, but there is nonetheless a clear discrepancy between the range of $T$. varians in the UK and in the USA. We cannot be certain whether this reflects a much earlier local 


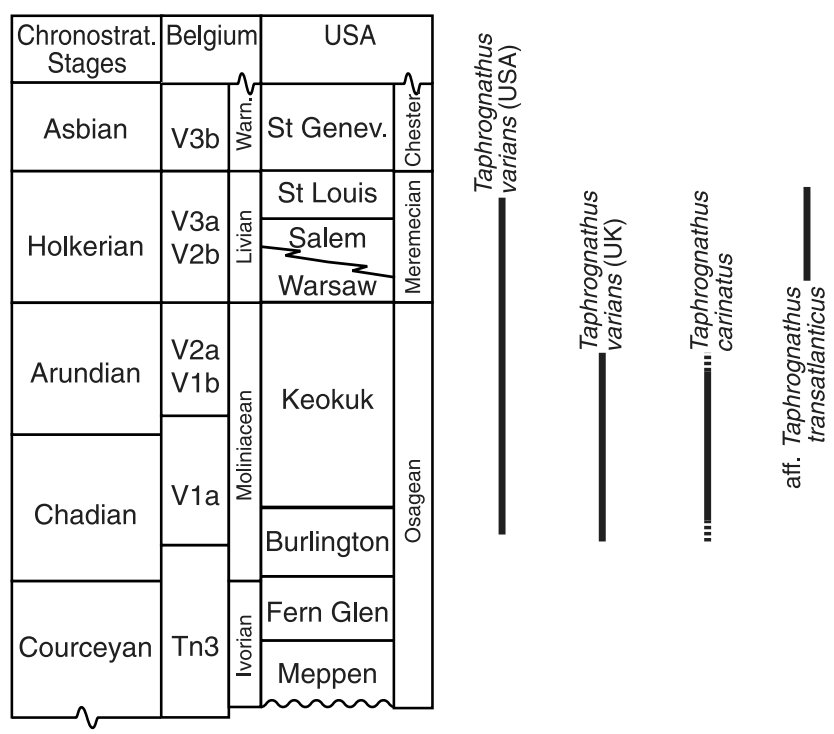

Fig. 2. Ranges of $T$. varians, $T$. carinatus and aff. $T$. transatlanticus. Chronostratigraphic stages are those used by Harland et al. (1990). Correlation of the Belgian and USA sequences with chronostratigraphy is based on Brenckle \& Manger (1991).

extinction of the species in the UK (i.e. ecological control), incomplete knowledge of the range of $T$. varians in the UK, or errors in the correlation of the sequence in the USA with the chronostratigraphic zones shown in Figures 1 and 2. It is pertinent to note that similar problems occur with Cavusgnathus unicornis; in the UK it first appears in the middle Arundian (Varker \& Sevastopulo, 1985), just after the last appearance of $T$. varians, but in the USA it appears in the upper St Louis Formation (i.e. late Holkerian). This is much later than in the UK, but in both areas it appears in the latest part of the local range of $T$. varians.

Higgins et al. (1991) indicated that in western Canada $T$. varians ranged from the upper Tournaisian into the lower Viséan, with 'Cloghergnathus' sp. occurring in the lower Viséan. They illustrate one $\mathrm{P}_{1}$ element of 'Cloghergnathus' sp. but this specimen does not look like any taphrognathid species known to us.

Taphrognathus carinatus is known from Ravenstonedale, Cumbria, UK, and from the Lower Border Group and equivalent strata in North Cumbria and Northumberland, UK. These localities were deposited in shallow, restricted marine environments (Higgins \& Varker, 1982; Purnell, 1989). The specimen of T. carinatus from Mazy, Belgium (Pl. 1, figs 7-9; see above) comes from a horizon that falls within the upper part of the range of the species as shown in Figure 2. This occurrence extends the geographical range of the species beyond the UK, but the species has not been found elsewhere. Krukowski (1990) identified $40 \mathrm{P}_{1}$ elements $T$. carinatus from the Kelly Limestone of New Mexico, USA, but the specimens he figured are $T$. varians. We cannot be sure of the identification of his unfigured material: he stated (p. 171) that 'most specimens from the Kelly Limestone have broken blades. Fortunately the posterior [ $=$ dorsal $]$ tips of most elements were intact and identified as Cloghergnathus carinatus by their posterior [= dorsal] carina', but this is not a character that allows $T$. carinatus to be differentiated from $T$. varians. Consequently, the occurrence of $T$. carinatus in the USA remains unproven. At present, the stratigraphic range of $T$. carinatus is difficult to determine. This is primarily because of the taxonomic problems created by Higgins \& Varker's (1982) inclusion of some T. varians within their concept of $T$. carinatus. In the Northumberland Basin $T$. carinatus occurs in the lower half of the $T$. varians local range biozone, but it is very uncommon and its stratigraphic distribution is very sporadic. The Chadian to Arundian age range shown on Figure 2 must be considered tentative, and the true range of $T$. carinatus may prove to be narrower than this. However, the presence of $T$. carinatus in Belgium at least suggests that it may be possible to correlate the 'shallow shelf' conodont biozonations of the 'type' Lower Carboniferous of northern England with the 'basinal' zonation erected in the type Dinantian of Belgium.

aff. Taphrognathus transatlanticus occurs in the Windsor and Codroy groups of Atlantic Canada (von Bitter, 1976; von Bitter \& Plint-Geberl, 1982; von Bitter \& Austin, 1984; Plint \& von Bitter, 1986; von Bitter \& Plint, 1987), and the Avon Gorge of SW England (von Bitter \& Austin, 1984). The occurrence of the species in a narrow stratigraphic interval within the Holkerian on both sides of the Atlantic led von Bitter \& Austin (1984) to suggest that the range zone defined by this species may be of considerable importance in international correlation. The possible occurrence of aff. T. transatlanticus in Belgium (Conil et al., 1991) thus assumes considerable significance.

However, the specimen of Taphrognathus carinatus from Mazy, Belgium, illustrated and described here comes from among the 'few small taphrognathids' upon which Conil et al.'s (1991) tentative T. transatlanticus zone was based. We have been unable to study the remainder of the collection of 'taphrognathid-like' conodonts to which Conil et al. (1991) referred, and we are unable to determine if they are all $T$. carinatus. If they are, then the Belgian specimens extend the stratigraphic range of the species considerably; Conil et al. (1991, fig. 2) show aff. T. transatlanticus ranging up to a level equivalent to the mid-Asbian. It is possible that some of these Belgian taphrognathids may be aff. T. transatlanticus but we are unable to confirm this. Consequently, even informal recognition of the Taphrognathus transatlanticus Range Zone in Belgium must be considered premature.

\section{ACKNOWLEDGEMENTS}

For access to collections, loans of type specimens, and permission to take scanning electron photomicrographs we would like to thank Ray Ethington (University of Missouri-Columbia), John Whittaker (Natural History Museum, London) and Steve Tunnicliffe (formerly of the British Geological Survey, Keyworth). Natural History Museum specimen PM X 1014 is re-illustrated with the permission of the Palaeontological Association and Alan Higgins. The manuscript benefited from a detailed review by Carl Rexroad. MAP is funded by NERC Advanced Research Fellowship GT5/98/4/ES.

\section{Manuscript received 12 February 2001 Manuscript accepted 17 May 2002}




\section{REFERENCES}

Armstrong, H.A. \& Purnell, M.A. 1987. Dinantian conodont biostratigraphy of the Northumberland trough. Journal of Micropalaeontology, 6: $97-112$.

Austin, R.L. 1974. Modification of the British Avonian conodont zonation and a reappraisal of European Dinantian conodont zonation and correlation. Extrait des Annales de la Société géologique de Belgique, 96: 523-532.

Austin, R.L. \& Davies, R.B. 1984. Problems of recognition and implications of Dinantian conodont biofacies in the British Isles. In: Clarke, D.L. (Ed.), Conodont Biofacies and Provincialism. Geological Society of America, Boulder, Colorado. Special Paper, 196, 195-228.

Austin, R.L. \& Mitchell, M. 1975. Middle Dinantian platform conodonts from County Fermanagh and County Tyrone, Northern Ireland. Bulletin of the Geological Survey of Great Britain, 55: 43-54.

Baxter, S. 1984. The Eotaphrus - Bactrognathus Zone, a new name for a conodont zone from the type Burlington Formation. In: Sutherland, P.K. \& Manger, W.L. (Eds), IX International Congress of Carboniferous Stratigraphy and Geology, Compte Rendu. Urbana, Illinois, 247-252.

Baxter, S. 1984. Conodont succession in the Mississippian of Southern Canada. In: Sutherland, P.K. \& Manger, W.L. (Eds), IX International Congress of Carboniferous Stratigraphy and Geology, Compte Rendu. Urbana, Illinois, 253-264.

Bengtson, P. 1988. Open nomenclature. Palaeontology, 31: 223-227.

Branson, E.B. \& Mehl, M.G. 1941. Conodonts from the Keokuk Formation. Denison University Bulletin, Journal of the Scientific Laboratories, 35: 179-188.

Brenckle, P.L. \& Manger, W.L. (Eds) 1991. International Correlation and Division of the Carboniferous System. Courier Forschungsinstitut Senckenberg, 130: 1-350.

Chaplin, J.R. 1984. Conodont biostratigraphy of Lower Carboniferous strata in the southern Appalachians. In: Sutherland, P.K. \& Manger, W.L. (Eds), IX International Congress of Carboniferous Stratigraphy and Geology, Compte Rendu. Urbana, Illinois, 265-281.

Collinson, C., Scott, A.J. \& Rexroad, C.B. 1962. Six charts showing biostratigraphic zones, and correlations based on conodonts from the Devonian and Mississippian rocks of the Upper Mississippi Valley. Illinois State Geological Survey, Circular, 328: 1-32.

Collinson, C., Rexroad, C.B. \& Thompson, T.L. 1971. Conodont zonation of the North American Mississippian. In: Sweet, W.C. \& Bergstrom, S. (Eds), Symposium on conodont biostratigraphy. Memoir of the Geological Society of America, 127: 353-394.

Conil, R., Groessens, E. \& Pirlet, H. 1976. Nouvelle charte stratigraphique du Dinatien type de la Belgique. Annales de la Socièté géologique du Nord, 116: 363-371.

Conil, R., Groessens, E., Laloux, M., Poty, E. \& Tourneur, F. 1991. Carboniferous guide foraminifera, corals and conodonts in the Franco-Belgian and Campine basins: their potential for widespread correlation. In: Brenckle, P.L. \& Manger, W.L. (Eds), International Correlation and Division of the Carboniferous System. Courier Forschungsinstitut Senckenberg, 130: 15-30.

Cossey, P.J. \& Adams, A.E. 2003. Stainmore Basin and Askrigg Block. In: Cossey, P.J., Adams, A.E., Whyte, M.A., Purnell, M.A., Wright, V.P. \& Whiteley, M.J. (Eds), British Lower Carboniferous Stratigraphy. Geological Conservation Review Volume, 29: JNCC, Peterborough.

Garwood, E.J. 1913. The Lower Carboniferous succession in the northwest of England. Quarterly Journal of the Geological Society, London, 68: $449-586$.

Groessens, E. 1974. Preliminary range chart of conodont biozonation in the Belgian Dinantian. In: Bouckaert, J. \& Streel, M. (Eds), International Symposium on Belgian Micropaleontological Limits. Geological Survey of Belgium, Brussels, 17, 1-193.

Hance, L., Hennebert, M. \& Overlau, P. 1981. Revision stratigraphique et sedimentologique du Tournaisien superieur (Ivorien) et du Viséan inferieur (Moliniacien) de la vallée de l'Orneau, Belgique. Memoires de l'Institut Geologique de l'Universite de Louvain, 31: 183-207.

Harland, W.B., Armstrong, R.L., Cox, A.V., Craig, L.E., Smith, A.G. \& Smith, D.G. 1990. A geologic time scale, 1989. Cambridge University Press, Cambridge.
Higgins, A.C. \& Varker, W.J. 1982. Lower Carboniferous conodont faunas from Ravenstonedale, Cumbria. Palaeontology, 25: 145-166.

Higgins, A.C., Richards, B.C. \& Henderson, C.M. 1991. Conodont biostratigraphy and paleoecology of the Uppermost Devonian and Carboniferous of the Western Canada Sedimentary Basin. In: Orchard, M.J. \& McCracken, A.D. (Eds), Ordovician to Triassic conodont paleontology of the Canadian Cordillera. Geological Survey of Canada Bulletin, 417: 215-251.

Jeppsson, L. \& Merrill, G.K. 1982. How best to designate obsolete taxonomic names and concepts: examples among conodonts. Journal of Paleontology, 56: 1489-1493.

Krukowski, S.T. 1990. Conodont and foraminifer biostratigraphy of the Kelly Limestone (Mississippian), west-central New Mexico. Unpublished PhD Thesis. New Mexico Institute of Mining \& Technology, Socorro, NM, United States, 1-363.

Matthews, S.C. 1973. Notes on open nomenclature and on synonymy lists. Palaeontology, 16: 713-719.

Metcalfe, I. 1981. Conodont zonation and correlation of the Dinantian and early Namurian strata of the Craven Lowlands of northern England. Institute of Geological Sciences, Great Britain, Report, 80/10: $1-70$.

Paproth, E., Conil, R. \& Bless, M.J.M. et al. 1983. Bio- and lithostratigraphic subdivisions of the Dinantian in Belgium; a review. Annales de la Société géologique de Belgique, 106: 185-239.

Plint, H.A. \& von Bitter, P.H. 1986. Windsor Group (Lower Carboniferous) conodont biostratigraphy and palaeoecology, Magdalen Islands, Quebec, Canada. Canadian Journal of Earth Sciences, 23: 439-453.

Purnell, M.A. 1989. Dinantian shallow shelf conodonts of the Northumberland trough. Unpublished $\mathrm{PhD}$ Thesis. University of Newcastle-Upon-Tyne, 1-335.

Purnell, M.A. 1992. Conodonts of the Lower Border Group and equivalent strata (Lower Carboniferous) in northern Cumbria and the Scottish Borders. Royal Ontario Museum, Life Sciences Contributions, 156: $1-79$.

Purnell, M.A. \& von Bitter, P.H. 1992. Vogelgnathus Norby and Rexroad (Conodonta): new species from the Lower Carboniferous of Atlantic Canada and Northern England. Journal of Paleontology, 66: 311-332.

Purnell, M.A., Donoghue, P.C.J. \& Aldridge, R.J. 2000. Orientation and anatomical notation in conodonts. Journal of Paleontology, 74: $113-122$.

Rexroad, C.B. \& Collinson, C. 1963. Conodonts from the St Louis Formation (Valmeyeran Series) of Illinois, Indiana and Missouri. Illinois State Geological Survey, Circular, 355: 1-28.

Rexroad, C.B. \& Varker, W.J. 1992. The new Mississippian conodont genus Synclydognathus. Journal of Paleontology, 66: 165-170.

Rhodes, F.H.T., Austin, R.L. \& Druce, E.C. 1969. British Avonian (Carboniferous) conodont faunas, and their value in local and intercontinental correlation. Bulletin of the British Museum (Natural History), Geology Supplement, 5: 1-313.

Riley, N.J. 1993. Dinantian (Lower Carboniferous) biostratigraphy and chronostratigraphy of the British Isles. Journal of the Geological Society, London, 150: 427-446.

Ruppel, S.C. 1979. Conodonts from the Lower Mississippian Fort Payne and Tuscumbia formations of northern Alabama. Journal of Paleontology, 53: 55-70.

Savage, N.M. \& Barkeley, S.J. 1985. Early to middle Pennsylvanian conodonts from the Klawak Formation and the Ladrones Limestone, southeastern Alaska. Journal of Paleontology, 59: 1451-1475.

Sweet, W.C. 1988. The Conodonta: morphology, taxonomy, paleoecology, and evolutionary history of a long-extinct animal phylum. Oxford monographs on geology and geophysics, 10: 1-212.

Thompson, T.L. 1967. Conodont zonation of Lower Osagean rocks (lower Mississippian) of southwestern Missouri. Missouri Geological Survey, Report of Investigations, 39: 1-88.

Thompson, T.L. \& Fellows, L.D. 1970. Stratigraphy and conodont biostratigraphy of Kinderhookian and Osagean (lower Mississippian) rocks of southwestern Missouri and adjacent areas. Missouri Geological Survey, Report of Investigations, 45: 1-263. 
Varker, W.J. \& Sevastopulo, G.D. 1985. The Carboniferous System: part 1 - conodonts of the Dinantian Subsystem from Great Britain and Ireland. In: Higgins, A.C. \& Austin, R.L. (Eds), A Stratigraphical Index of Conodonts. Ellis Horwood, Chichester, 167-210.

Welles, S.P. 1947. Vertebrates from the upper Moenkopi formation of northern Arizona. University of California, Geological Science Bulletin, 27(7): 241-294.

von Bitter, P.H. 1976. Paleoecology and distribution of Windsor Group (Visean-?Early Namurian) conodonts, Port Hood Island, Nova Scotia, Canada. In: Barnes, C.R. (Ed.), Conodont Paleoecology. Geological Association of Canada, Special Paper, 15: 225-241.

von Bitter, P.H. \& Austin, R.L. 1984. The Dinantian Taphrognathus transatlanticus conodont range zone of Great Britain and Atlantic Canada. Palaeontology, 27: 95-111. von Bitter, P.H. \& Plint, H.A. 1987. Conodonts of the Windsor Group (Lower Carboniferous), Magdalen Islands, Quebec, Canada. Journal of Paleontology, 61: 346-362.

von Bitter, P.H. \& Plint-Geberl, H.A. 1982. Conodont biostratigraphy of the Codroy Group (Lower Carboniferous), southwestern Newfoundland, Canada. Canadian Journal of Earth Sciences, 19: 193-221.

von Bitter, P.H., Sandberg, C.A. \& Orchard, M.J. 1986. Phylogeny, speciation, and palaeoecology of the Early Carboniferous (Mississippian) conodont genus Mestognathus. Royal Ontario Museum, Life Sciences Contributions, 143: 1-115. 